\title{
The Effect of Stakeholder Inclusion on Public Sector Project Innovation
}

\section{Godenhjelm, Sebastian}

2018-03

Godenhjelm , S \& Johanson, J-E 2018 , ' The Effect of Stakeholder Inclusion on Public

Sector Project Innovation ' , International Review of Administrative Sciences , vol. 84 , no. 1 , pp. 42-62 . https://doi.org/10.1177/0020852315620291

http://hdl.handle.net/10138/233263

https://doi.org/10.1177/0020852315620291

acceptedVersion

Downloaded from Helda, University of Helsinki institutional repository.

This is an electronic reprint of the original article.

This reprint may differ from the original in pagination and typographic detail.

Please cite the original version. 


\title{
The Effect of Stakeholder Inclusion on Public Sector Project Innovation
}

\section{Sebastian Godenhjelm and Jan-Erik Johanson}

Sebastian Godenhjelm

Swedish School of Social Science

PB 16, 00014 University of Helsinki

Finland

Jan-Erik Johanson

School of Management (JKK)

FI-33014 University of Tampere

Finland

\section{Running head:}

\section{Stakeholder inclusion and project innovation}

\begin{abstract}
The delivery of public services in collaborative agency networks has given rise to an increasing use of projects in administering policy and service delivery. Projects are assumed to provide mechanisms by which flexibility can be achieved and innovative solutions produced. The aim of the article is to advance the understanding of collaboration between stakeholders and its effect on innovation. It analyses stakeholders influence on the creation of project innovations in 275 EU funded projects by using content analyses and logistic regression analyses. The results show that projects can act as hubs where valuable information is produced but that few projects produce innovations. Project stakeholder network, knowledge dissemination, project influence, as well as sources for advice plays a role in predicting project innovations. The article concludes that the overly optimistic view of collaboration as a remedy for a lack of innovation in the public sector can be questioned.
\end{abstract}




\section{Points for practitioners}

The results of the article help practitioners to compose public sector development projects that foster innovation. The results suggest that it pays off to include representatives of research and education facilities among the project staff as their inclusion predicts the possibilities to achieve innovations. The empirical findings provide insight into project innovation and indicate which practices to avoid. It suggests that distance from the well-established democratic power regime and from corporate governance regime is rewarding, and that when managed correctly stakeholder inclusion has an effect on public sector project innovation.

\section{Keywords}

Citizen participation, Implementation, Networks, Partnerships, Public Administration, Public management, Regional and Local Government, Service delivery

\section{Introduction}

Innovation represents the core of renewal processes in organizations and is regarded as the key driver in organizational success as well as a solution to welfare problems (McCann and Ortega-Argiles, 2013). However, innovation in governance is ambiguous and requires an institutional environment that fosters learning and knowledge sharing (Hartley, 2005). A common notion is that knowledge is created when heterogeneous organizations or actors meet, create partnerships and share ideas. Thus, some see creative problem solving and collaboration as the cure for the alleged innovation deficit within the public sector (Bommert, 2010; Borins, 2014). Consequently many public management reforms and programmes identify innovation as their primary goal (Considine and Lewis, 2007).

\footnotetext{
International Review of Administrative Sciences $0(0) 1-2$

! The Author(s) 2016

Reprints and permissions:

sagepub.co.uk/journalsPermissions.nav

DOI: $10.1177 / 0020852315620291$
} 
European regional development strategies rely on the innovative capacities of networks and projects (Ansell, 2000). Projects are deemed well suited to the development of innovation (Brady and Hobday, 2011). Despite the optimistic assumptions there is a lack of studies that clarify the drivers of and barriers to collaborative innovation (Sørensen and Torfing, 2011). Studies point to the increasing need for facilitating inter-organizational structures and collaboration, as well as strategies to integrate multiple stakeholders into common projects (Briere and Proulx, 2013; Klijn, 2008; Michels, 2011). Evidence of the effect of collaborative governance is, however, inconclusive (Ansell, 2012).

Few examples of the systematic use of collaborative interaction that would help the public sector to create opportunities for collaborative innovations exist (Sørensen and Torfing, 2012). The project management literature tends to emphasize the positive view of collaboration, but it is evident that networking also bears cost in terms of time and energy involved in action (Burt, 1992; Nan, 2001). There is an increasing need to understand the prospects for collective and multilateral action, to evaluate possible gains of collaborative interaction.

The aim of this article is to identify beneficial social partners and to define useful actions intended to achieve innovation in EU funded projects. The overarching research question is to what extent collaborations are a prerequisite for innovation and what are the beneficial collaborative procedures and actions? 
The article is structured as follows. It begins by discussing how projects relate to the interactive governance debate and the public policy service delivery process. It goes on to discuss the concept of innovation and its drivers, and establishes a link between the collaborative governance debate and the possible determinants of innovation. It then describes the research setting and methods, presents the analysis, and ends with a concluding discussion and suggestions for future research.

Innovation through public sector collaboration

The degree to which the public sector can interact flexibly with private and other non-governmental actors is a key component of its innovation capacity. It underlies the idea of collaborative innovation by stressing that assets of diverse actors across organizational boundaries should be used (Bason, 2010; Bommert, 2010). Public sector collaboration is believed to offer opportunities to resolve unmet challenges, improve idea generation, implementation and diffusion, which bureaucratic forms cannot offer (Bommert, 2010).

A commonly used definition of innovation is that it is "...implementation of a new or significantly improved product (good or service), or process, a new marketing method, or a new organizational method in business practices, workplace organization or external relations' (OECD and Eurostat, 2005). Other definitions cover positions where products or services are used, and innovations as new 
paradigms signifying a new mental model (Bessant and Tidd, 2007; Rowley et al., 2011). Innovation can also be viewed as policy-makers that enable innovation through legislative reforms or by providing resources for experiments that enable collaboration (Hartley, 2005).

The term innovation is often narrowly defined, and policy discussions often underestimates the complexity of the innovation process (Christopherson et al., 2008). Innovation type definitions also overlap and can encompass hybrid forms such as products that include both services and product innovations (Rowley et al., 2011). A predominant feature within most definitions is that innovations are seen as tools by which increased competitiveness and commercialization can be achieved.

In public administration problems usually need to be solved by a wide audience that extends beyond resources controlled by any given organization (Collm and Schedler, 2014; Eggers and Singh, 2009). Knowledge sharing is therefore valuable, and is believed to increase government innovation processes (Kim and Chang, 2009) by enabling creative processes that bring an alternative mode of knowledge to the forefront (Bason, 2010). Collaboration among actors that alters broad social conditions of collective concern are particularly important (Moore and Hartley, 2008), creating a wider palette of options and bringing assets in terms of knowledge, imagination, creativity, and political authority into play (Bommert, 2010). The 
identification of gatekeepers that connect local systems with external knowledge sources and act as knowledge brokers, are therefore of particular importance (Brenner et al., 2013).

\section{Projects as spaces for collaborative innovation}

Contemporary society is increasingly focusing on interactive governance measures, where the State collaborates with civil society and markets through networks, micro-level feedbacks as well as meso-level interactions (McCann and OrtegaArgiles, 2013; Torfing et al., 2012). The introduction of the EU partnership principle has increased stakeholder involvement in the policy process, by including different actors at local and regional levels, thereby emphasising a multi-stakeholder and multi-institutional policy framework (Jordana et al., 2012; McCann and OrtegaArgiles, 2013). As a result, temporal and spatial horizons for strategic action have become increasingly important. Despite these developments few studies point directly at projects.

Projects are temporary endeavours that are expected to create unique products, services or results (Project Management Institute, 2004). They are comprised of different sequences, beginning with action-based entrepreneurship where the impetus of the project is created. The project is then fragmented into specific work packages which are isolated so that the project can focus on completing the task at 
hand, after which it is terminated (Lundin and Söderholm, 1995). Project work can, however, not be regarded as totally secluded. Mechanism for adaption between permanent and temporary project organisations are essential (Godenhjelm et al., 2015).

The focus on project scope and its temporal limitation also affects knowledge creation because of the value in solving a particular problem or task. Projects are believed to bring about creativity that meets the requirements of innovation (Bason, 2010; Brady and Hobday, 2011). They usually involve a network of stakeholders, and should serve as collaborative forums where knowledge is effectively produced and shared (Eggers and O'Leary, 2009). Knowledge is believed to arise at the interface between projects and other actors involved. Learning is expected to be rooted in the repeated cycles of interaction between the project and the associated organizations (Grabher, 2004). In a relational sense, being an individual, stakeholder or project isn't about the attributes, such as the duration or budget, but about the accumulated contacts with stakeholders, organizations and projects (i.e., the project network).

The diverse stakeholder group interests make the assessment of public sector networks difficult. Network management might be based on formal position of one organization or informal adjustments of individual partners. A review of findings of complete networks (Provan et al., 2007) suggests that network administrative 
organization created to support network leadership might be instrumental in providing both the virtues of flexibility and coordination without imposing too much formal rigidity on the interaction.

Two network features are especially important; brokering, which has an impact on the number of ties (density) in a network, and network control, ranging from participant governed networks to those controlled by organizations. This relates to the usefulness of weak and strong ties for reaching innovations. Strong ties refer to intimate, frequent and emotional ties whereas weak ties signify distant, infrequent and superficial contacts. The power of weak ties is in their ability to provide new information because they overlap boundaries between social circles. Strong ties tend to be concentrated on a set of tightly-knit groups that hold the same information (Granovetter, 1985; Koschatzky et al., 2001). Ideally, these networks should be managed in a non-hierarchical, collaborative way. Project participation can therefore be analysed as networks of relationships or strategically coordinated inter-firm, yet project based relationships (Pryke, 2006).

Project stakeholder composition. Public sector projects include a multitude of actors from private and public organizations. The project management literature defines these actors as project stakeholders, meaning individuals or organizations that either are involved in or affected by the project, and whose requirements and 
expectations need to be determined and managed. Core stakeholders consist of project organization staff or steering group members. They should constitute the optimal composition in order to successfully complete the project task, and are greatly affected by the project. Primary and/or secondary stakeholders consist of actors or organizations without explicit decision-making authority in the project. They are only to some extent affected, and are less likely to actively influence the project (Project management Institute, 2004).

Stakeholders might be included as a response to unexpected events such as misunderstandings between the focal project organization and local stakeholders (Aaltonen et al., 2010). Failure to include key stakeholders might cause serious damage to the project, especially if unplanned events occur (Wirick, 2009).

Project stakeholder involvement. Stakeholder involvement is crucial for creating ownership and implementation. Different activities can be included under this concept, ranging from anchoring the project in its institutional environment to exercises such as "visioning", which may contribute to decision-making (Aaltonen et al., 2010; Ansell, 2012).

Knowledge exchange between stakeholders is believed to help identify problems and to develop strategies for dealing with complexities (Sørensen and Torfing, 2012). This includes identifying what information should be disseminated and what 
type of input is required (El-Gohary et al., 2006). The involvement and selection of stakeholders requires activity by the project organization. The selection of communication channels to inform stakeholders about the project, how it will proceed, as well as knowing who to turn to for advice is central.

Involvement does not mean that all stakeholders need to agree with project decisions. Exchange of resources and ideas, as well as the sharing of risks and benefits is, however, necessary to achieve the benefits of innovation. Mere competition and bureaucracy is destined to fail as actors only fight each other all the way to the patent office (Sørensen and Torfing, 2012).

Ideally, project stakeholder collaboration builds up relationships, increases trust, establishes a common ground, that provides a fruitful ground for innovation (Grabher, 2004). This is also the main idea of the EU partnership principle. Critically speaking, stakeholders might, however, also be included for purely symbolic reasons or to promote conformity rather than variety and innovation. In addition, stakeholders might not be able or willing to contribute to the task at hand (Loorbach, 2010).

Project stakeholder knowledge brokers. Both inclusion and involvement can occur as a result of contacts within the epistemic community or within personal networks associated with the projects (Grabher, 2004). Identifying stakeholders that can act 
as knowledge brokers is important (Kauffeld-Monz and Fritsch, 2013). Equally important is the involvement of innovation entrepreneurs, who are able to articulate problems, opportunities and propositions for solutions, and who can mobilize both material and non-material resources (Sørensen and Torfing, 2012). The involvement of actors who have access to knowledge beneficial for the project is fundamental, not only in terms of innovation creation but also to ensure institutional embeddedness (Bommert, 2010). Previous collaboration can build trust and establish a common ground among stakeholders (Gulati, 1995; Uzzi, 1997). Gaining access to either project staff or project stakeholders that contribute to lessons learned in previous projects is important (El-Gohary et al., 2006). New stakeholders can also create a critical mass that fosters innovative developments. It is therefore important to identify stakeholders outside of stable networks that consist of the "usual suspects" whose similar views might create lock-in situations that stifle creativity (Skilton and Dooley, 2010).

The suitable interaction patterns depend upon the boundaries to be crossed as well as the knowledge to be transferred. Carlile (2002) distinguishes syntactic, semantic and pragmatic boundaries in creating innovations. In syntactic settings the common lexicon exists among cooperative partners. It is a question of knowledge transfer in which the technical aspects of information exchange dominates the interaction. Semantic boundaries are based on lack of common interpretation, which requires 
extensive interaction in building trust among the partners and might result in developing new shared meanings (Nonaka and Takeuchi, 1995). Pragmatic boundaries are marked by both differences of interpretation, and by differences of interests. Here, the negotiation of interests and creation of jointly workable boundary objects might induce new understanding of the knowledge itself. Overcoming semantic and pragmatic boundaries requires variety of brokering activity (Fernandez and Gould, 1994).

The discussion above suggests that stakeholder involvement is not a 'one-size-fitsall' approach. The inclusion of a broad range of stakeholders and the selection of the most suitable composition of actors, actions fostering stakeholder involvement, and knowledge brokers should increase the odds of a project innovation.

\section{Research setting, material, and methods}

The need for innovation is strongly emphasized in the European Union (European Parliament and the Council of the European Union, 2006) According to its Lisbon Strategy the EU should aim to become "the most competitive and dynamic knowledge-based economy in the world capable of sustainable economic growth with more and better jobs and greater social cohesion" (European Union, 2000). Innovation plays a particularly important part in Finland where the public sector is dependent on the production of innovation to foster economic development. 
Finland is also regarded as one of the most innovative countries in the world, superseded only by Switzerland, the United Kingdom and Sweden (Dutta et al., 2014)

EU programme objectives are primarily implemented through small, well-focused projects at local level. Since its initiation on the $1^{\text {st }}$ of January 2007 , the 2007-2013 programming period had funded 1188 European Regional Development Fund (ERDF) projects in Finland that were completed by the 31 $1^{\text {st }}$ of December 2012. Almost half (44\%) of these were categorised as EU priority axes 2 projects, which specifically funded projects that promote innovation activity and networking, and reinforce knowledge structures (Suomen rakennerahastostrategia, 2007). All projects that received funding within this priority axes were expected to produce innovations.

The material used in this paper consists of all ERDF innovation development projects in Finland during this period $(\mathrm{N}=328)$. The material is limited to projects with different project managers, making the amount of projects included in the analysis 275 , or $84 \%$ of the population. The material is based on archival data from the EURA2007 database where mandatory information on all EU funded ERDF projects in Finland is stored. This material includes information about project finances, stakeholders, indicators, and projects' final reports (Ministry of Labor and the Economy, 2014). In addition, survey data was gathered during summer 2013. 
The survey was sent to the above mentioned 275 project managers who had received EU funding for innovation projects ${ }^{1}$, and had a response rate of $41.8 \%$.

The methods used in the article include descriptive and qualitative content analysis, as well as logistic regression analysis. The descriptive analysis focused on identifying the projects' goals and their organizational background as well as the mapping of companies and organizations linked to individual projects. The qualitative content analysis (Schreier, 2014) was used to identify innovations that the projects produced. The logistic regression analysis was used to establish a link between project collaborations and innovation. Apart from the regression coefficients of the variables, the results of the exponentiated regression coefficients (odds) illustrates the relative increase in the probability of innovation occurring when there is a unit change in the independent variable. In the analysis employed, odds greater than one indicate an increased "chance" of achieving innovation by including a particular actor or taking a particular social action by contrast with not including the particular partner or not taking some social action. The small sample size made it necessary to include variables one by one in the analysis.

The operationalization of the key variables

The dependent variable is innovation, and the independent variables organisational background and collaboration. Innovation was operationalised by analysing archival 
data on the projects' final reports using qualitative content analysis. The analysis was conducted by constructing a coding frame of four different innovation types based on the 4Ps of innovation defined by Bessant and Tidd $(2007,13)$. This provided the characteristic of the category, telling the coder when a given category was applicable, thereby enabling the extraction and coding of different innovation categories from the final reports.

The innovation variable and its categories were defined in the following way:

- Product innovations indicated results relating to changes in the things (products/services) which an organization offers

- Process innovations indicated changes in the ways in which things (products/services) are created and delivered

- Position innovations indicated changes in the context in which the products/services are introduced

- Paradigm innovations indicated changes in the underlying mental modes which frame what an organization does

The variable scored zero if the information in the projects' final report did not correspond to any features of a particular innovation type and one if any of the innovation categories were present ${ }^{2}$. 
The independent variables were studied in the following way. The projects' organizational background was operationalised by analysing archival data on project characteristics budget and duration. The total budget in Euros (Log) was included in the analysis, and the duration of the project was coded in months. Collaboration analysed project composition, knowledge brokers and project involvement.

Project composition encompassed project staff, steering group, and stakeholder inclusion. Staff inclusion was analysed using archival data on which organization project staff members previously had belonged or currently belonged to. The variable was coded so that one indicated presence of the same organisation and zero indicated no presence. Project steering group inclusion was analysed using survey data on which organization project staff members previously had belonged or currently belonged to. The individual steering group inclusion predictors were coded as one for presence in the same project and zero for absence. Project stakeholder inclusion was analysed using archival data on the amount of stakeholders included in projects. The number of reported stakeholders (log) was included in the examination.

Knowledge brokering encompassed studying archival data on interlinking project staff and project stakeholder members. This included members that currently were, or previously had been, included in other similar EU innovation projects during the 
same programming period. Interlinking project staff was operationalized by analysing overlapping memberships in other projects. The requirement for being defined as project staff member was having one of the following roles in the project: project manager, economy manager, administrator, person in charge of the project, person in charge of the follow up of the project. Interlinking project stakeholders were operationalized by analysing overlapping stakeholder memberships in other projects. The analysis included all actors categorised as stakeholders in the projects' final reports. The requirement for being categorized as a stakeholder was to have participated in the project's activity, such as participation in the development of a process, service or result. Both interlinking stakeholder members and interlinking project staff members were coded one if two or more projects shared at least one project employee or at least one project stakeholder (degree of centrality $\geq 0$ ) and zero otherwise (Scott, 2007, 83).

Finally, involvement encompassed survey data on stakeholder information, means of influence and sources for advice. Stakeholder information was operationalized by analysing which forums that were used to disseminate knowledge about the project. The variable was coded so that one indicated the use of a particular forum and zero indicated no use. Means of influence was operationalized by analysing the methods used by the project to affect project outcomes. The variable was coded so that one indicated the use of a particular method and zero indicated no use. Source of advice 
was operationalized by analysing to whom the project had turned to for advice on matters related to the project.

\section{Project innovations and stakeholder collaboration}

Almost all ERDF projects stated in their final reports, that their project produced innovations. The analysis of project innovations, however, showed that only 37 of the 275 project results could be identified as a specific or a hybrid innovation type that corresponded to the 4P definition of innovations ${ }^{3}$. The majority of innovations found were either process innovations (24), such as the development of new operational models within care of the elderly, or product innovations (24) such as a new type of laser that can be used in both laboratory conditions as well as in welding. Only one position innovation was identified and no paradigm innovations were found. The results are also summarized in figure 1.4

[INSERT Figure 1. Summary of the results of the logistic regression analysis predicting innovation]

Organizational background and innovation. The ERDF innovation projects ranged from small budget projects to multi-million euro projects. On average, they 
lasted two and a half years and included 40 stakeholders per project, most of which were categorized as privately held companies. All in all, almost 11,000 stakeholders were involved.

The analysis of project characteristics showed that project budget and duration play a role in achieving innovation. The results on the effect of organizational background on project innovation in this sense showed that, "you get what you paid for" as the variables related to the size of the project (budget and duration) were positive indicators of the innovation taking place. These aspects are also highly interdependent, which in terms of social networks means that including a large number of stakeholders also requires financial and temporal resources.

\section{Composition and innovation}

The analysis showed that projects use a wide base of actors with different occupational backgrounds as stakeholders, staff or steering group members. This should provide good conditions for new ideas to be discovered, developed, and implemented (Eggers and Singh, 2009).

In terms of staff composition the analysis showed that over two-thirds of all projects included at least some staff member(s) that either currently worked or had previously worked within research and education. Similarly, almost $67 \%$ of all projects indicated that they included staff members who either currently worked or 
had previously worked within privately owned firms. The results also showed that staff composition from various employment backgrounds had a positive effect on the occurrence of innovation. Staff members from privately owned companies or from the research and education sector was a positive predictor of innovation. This is in line with previous results that stress the importance of including organizations that can act as brokers of globally dispersed knowledge (Kauffeld-Monz and Fritsch, 2013). However, the inclusion of staff from municipalities or federations of municipalities, as well as staff members from national and/or regional authorities also had a positive effect.

Secondly, in terms of steering group members, almost all projects included members representing local associations, regional administration agencies and/or regional cooperation groups. A significant number of projects also had firms and municipalities as steering group members. Local associations were on average deemed as having little or no influence on the daily project activities while firms were perceived as being most influential.

The results showed that members from municipal development corporations, privately owned companies, and municipalities or federations of municipalities had a particularly positive effect on the occurrence of innovation. Members from both the research and education sector as well as from centres for economic development, transport and the environment (CEDTE) were also positively 
associated with innovation. The results, however, do not show what the nature of their presence was. It is possible that privately held companies contribute to information not associated with innovation but, for instance, with practical project management tools.

Finally, there are marked differences of activity between a large and small number of stakeholders. In the examination of the project documentation, it seems that projects with few external stakeholders revolved around developing new networking among actors within a specific technical field. On the other hand, projects with many stakeholders $(\geq 300)$ aimed at developing business clusters or think tanks, or activating the internationalization processes of SMEs. There is a distinction between the design and activity of the networks. Staff and steering group membership can and must be decided prior to project activation, whereas communication, influence and activity related to advice occurs only within the implementation phase of the project.

The results of the effect of project composition on project innovation suggests that the inclusion of a large number of stakeholders increases the odds of a project innovation, but more variety of actors does not per se equate to innovation. For instance, staff and steering group members from the voluntary sector did not have an impact, and only specific public sector agencies increased the odds of innovation. Further analysis of the archival material suggested that the local origin of the 
stakeholders might increase their usefulness for the project.

\section{Knowledge brokers and innovation}

As described above, projects with larger stakeholder networks had more potential for being innovative. A possible reason for this is that they may include either staff members of stakeholders that can act as brokers that can create an appropriate balance between regional know-how, and convey globally dispersed knowledge into the regionally situated networks or projects (Kauffeld-Monz and Fritsch, 2013). Finding suitable "innovation agents" that both facilitate knowledge transfer as well as embed the project in its institutional environment might thus be an important aspect beside the number of stakeholders.

The links between projects were investigated using two measures. One measured the connections provided by the project members, which were formed by the same employees working in multiple projects (i.e. interlinking project staff membership). Another type of connection was based on shared stakeholders (i.e. interlinking project stakeholder membership), which were formed by same stakeholders participating in multiple projects. The main difference here is that staff is hierarchically connected to their project whereas stakeholder participation can be fluid, ad hoc, and issue-related. The interlinkages between projects (shared staff or stakeholders) are, at least regarding staff membership, dictated by the funding 
decisions in the application phase.

Surprisingly, the results of the effect of knowledge brokers on project innovation showed that the selection of actors with interlinking memberships decrease the odds of a project innovation even though previous theoretical discussion suggests the opposite. Staff which has knowledge of many projects might emphasise the formal side of project processing and termination rather than innovative goal achievement. The same type of reasoning might apply to sharing previously known stakeholders that might form well connected communities in which everyone possesses the same knowledge base. Here, the contradiction with the strength of weak ties argument actually disappears as stakeholder sharing might induce strengthening of the relationships in the social structure between the projects which does not support the generation of new ideas.

This finding suggests implications of core, and secondary project stakeholders. The selection of suitable core stakeholder members are important for the innovativeness of the project, but the funding decision which dictates the interaction of different project cores can influence even the ability of the competent project core to meet its innovative goals. In terms of secondary stakeholder inclusion, projects need to select their partners with care. Even though stakeholder involvement can be fluid, the use of previously known partners among the project universe do not automatically create new ideas. The results highlight the 
importance of clustering among new actors in order to secure that the project does not remain stagnant.

The analysis of networks among interlinking project staff members showed that the majority of projects (75\%) had no connection with other staff members acting or having acted in other innovation projects. This was not the case for networks among interlinking project stakeholder members, where a significant amount of external stakeholders were involved in other projects as well (see figure 2).

\section{[INSERT Figure 2. Project external stakeholder involvement $(\mathrm{N}=275)^{5}$ ]}

\section{Involvement and innovation}

The vast majority of the respondents stated that new and innovative ideas evolved as a result of collaboration within the project, and that a wide variety of involvement techniques were used to foster involvement.

In terms of stakeholder information, the analysis showed that individual meetings, press releases and seminars were the most frequently used dissemination forums ${ }^{6}$. The analysis showed that the use of webpages and social media, public meetings, surveys, and workshops were positively associated with project innovation.

In terms of means of influence, the use of discussion groups, panels etc., contact with public officials, and the writing of newspaper articles were the most frequently 
used7. The analysis showed that discussion groups and panels, client or user surveys, and contacts with public officials stood out as particularly useful for increasing the odds of innovation.

In terms of sources for advice and to whom the project organization had turned to for advice in project related matters, the analysis showed that regional councils, privately owned companies and Universities were frequently turned to ${ }^{8}$. The analysis showed that these, as well as, municipalities, CEDTEs had a particularly strong connection with innovation.

The results of the effect of involvement on project innovation suggest that involvement increases the odds of a project innovation. However, the results also indicate that not all types of involvement are useful. Efforts to getting advice or influencing third sector organizations does, for instance, not pay off in terms of arriving to innovations.

\section{Concluding discussion}

The overarching research question was to analyse to what extent collaborations are a prerequisite for innovation and what the beneficial collaborative procedures and actions are? The conclusion specifies the conditions under which innovation can be a function of collaboration thereby contributing to the drivers of and barriers to 
collaborative innovation. Projects should also offer ideal conditions for innovations to emerge, and the empirical findings show that project organizations can act as collaborative spaces and include a multitude of stakeholders. A large number of stakeholders provide fertile ground for innovations to grow, but interlinks between project stakeholders inhibits the development of innovations. Organizing a project is not only selection between hierarchy or network, but also choosing between different types of networks with variety of alternative constellations. The article portrays the complexity associated with innovations in a public sector setting. A public sector presence in funding and operating innovative projects broadens the scope of innovation from new equipment to social and governance innovations. Pinpointing what counts as novel ideas and practices increases complexity as context is a relevant aspect in the process. While networks are built on stability and harmony, projects might accept a higher risk/reward ratio.

The results question value for money given the project innovation rate of only $13 \%$. All of the analysed projects should have produced innovations of some sort. The means by which project knowledge is disseminated, what types of influence the project uses, as well as to whom the project turns to for advice matters. While networks play a role in predicting innovations in ERDF projects, there is a clear indication that networks include both useful and redundant aspects as only some relationships and actions influence innovative behaviour. In terms of composition, 
local government presence, private firms and research and education facilities should be an integral part of the formal project structure when seeking innovation. However, in a network context it would be too hasty to argue for the removal of a specific partner as the extraction of any one network actor might change the structure of the network configuration as a whole. This has not been fully exploited in the current structural funding context.

The inclusion of a large number of stakeholders also brings forth the idea that some stakeholders are present not for the purposes of innovation, but as guarantees of legitimacy in the eyes of the funders.

The results add to the knowledge of successful knowledge brokering conditions by highlighting the importance of responsibility over the composing of the innovative project network. The project organization has a say on the composition of actors and it can choose various different involvement techniques during the project. However, many of the connections between projects through common stakeholders are defined by the decisions of funding bodies. This brings a top-down character to the linkages among the projects. It is up to the funding bodies to detect the potentially fruitful project-project contacts that lead to the emergence of innovations and best practices beyond the scope of a single project. Rounding up the usual suspects might be beneficial for project completion but not for innovation. Previously known actors might for instance be too set in their ways to think outside the box, or they might 
simply be too afraid of the repercussions of integrating radically new ideas that might jeopardise project completion. Clarifying this would, however, require further research on a case study level.

It might also be that funding bodies are unable to detect project linkages that would create the extra spark needed to bring about genuinely novel ideas and practices. This resonates well with the ideas put forward in previous research (Agranoff and Mcguire, 2003; Provan and Kenis, 2007) which encourages the establishment of overseeing bodies to monitor developments in the otherwise loosely-coupled networks. In the case of ERDF projects, the role of the funder is external to the actual functioning of the projects, but the connections between project staff members are instrumental in integrating the management of the innovation projects as a whole. The theoretical findings contribute to the interactive governance debate, particularly that on collaborative innovation. It questions the optimistic view of collaboration as a remedy for a lack of innovation in the public sector thereby increasing our knowledge of the effects of collaborative governance. If governance is a new form of administration replacing hierarchies, it makes sense to elaborate its alternative forms. The content of relationships, network configuration, and the actors included are the main ingredients in the composition of the networks.

All projects are unique by definition, which is highlighted in innovation projects. This also makes them context dependent, which in turn makes finding a one-size- 
fits all model difficult. Even if the findings in this article should not be taken as an absolute solution for the production of innovations in EU-funded projects, they clearly point to key factors that should be tested in the current innovation debate. This study thereby adds value to the existing literature by pointing out fruitful project involvement patterns to reach innovation. Even though contextual and practical distinctions between for instance the EU, North America, and developing countries exist the findings of this research establishes a baseline for future research and testing in settings outside of the EU. It is evident that organizations such as universities and multinational companies with unlimited research and development capacity that have traditionally been viewed as wellsprings for innovation are not enough in this project context. The emergence of project innovations also requires a functioning and facilitating permanent structure. Adequate resources that enable local and regional authorities and agencies to cooperate in project networks are important if the public sector is to be able to utilize the benefits of temporary project instruments in a meaningful way. 


\section{References}

Aaltonen K, Kujala J, Lehtonen P, et al. (2010) A stakeholder network perspective on unexpected events and their management in international projects. International Journal of Managing Projects in Business, 3(4), 564-588.

Agranoff R and Mcguire M (2003) Collaborative public management. Washington: Georgetown University Press.

Ansell C (2000) The Networked Polity: Regional Development in Western Europe. Governance, 13(2), 279-291.

Ansell C (2012) Collaborative Governance. In: Levi-Faur D (ed.), The Oxford Handbook of Governance, Oxford: Oxford University Press, pp. 498-511.

Bason C (2010) Leading public sector innovation. Co-creating for a better society. Bristol: The Policy Press.

Bessant J and Tidd J (2007) Innovation and Entrepreneurship. Chichester: John Wiley \& Sons, Inc.

Bommert B (2010) Collaborative innovation in the public sector. International public management review, 11(1), 15-33.

Borins S (2014) The Persistence of Innovation in Government : A Guide for Innovative Public Servants.

Brady T and Hobday M (2011) Projects and Innovation: Innovation and Projects. In: Morris P, Söderlund J, and Pinto J (eds), Oxford Handbook of Project Management, Oxford: Oxford University Press, pp. 273-296.

Brenner T, Cantner U and Graf H (2013) Introduction: Structure and Dynamics of Innovation Networks. Regional Studies, 47(5), 647-650.

Briere S and Proulx D (2013) The success of an international development project: lessons drawn from a case between Morocco and Canada. International Review of Administrative Sciences, 79(1), 165-186. 
Burt RS (1992) Structural holes. Massachusetts: Harvard University Press.

Carlile PR (2002) A Pragmatic View of Knowledge and Boundaries: Boundary Objects in New Product Development. Organization Science, 13(4).

Christopherson S, Kitson M and Michie J (2008) Innovation, networks and knowledge exchange. Cambridge Journal of Regions, Economy and Society, 1(2), 165-173.

Collm A and Schedler K (2014) Strategies for Introducing Organizational Innovation to Public Service Organizations. Public Management Review, Routledge, 16(1), 140-161.

Considine M and Lewis JM (2007) Innovation and Innovators Inside Government: From Institutions to Networks. Governance, 20(4), 581-607.

Dutta S, Lanvin B and Wunsch-Vincent S (2014) The Global Innovation Index 2014. The Human Factor in Innovation. The Global Innovation Index.

Eggers W and O'Leary J (2009) If we can put a man on the Moon... Getting Big Things Done in Government. Boston: Harvard Business Press.

Eggers W and Singh S (2009) The Public Innovator's Playbook: Nurturing Bold Ideas in Government. Winnipeg: Deloitte Research.

El-Gohary NM, Osman H and El-Diraby TE (2006) Stakeholder management for public private paertnerships.pdf. International Journal of Project Management, 595-604.

European Parliament and the Council of the European Union (2006) DECISION No 1639/2006/EC OF THE EUROPEAN PARLIAMENT AND OF THE COUNCIL of 24 October 2006 establishing a Competitiveness and Innovation Framework Programme (2007-2013).

European Union (2000) Lisbon European Council 23 and 24 March 2000. Presidency Conclusions. 
Fernandez RM and Gould R V. (1994) A Dilemma of State Power: Brokerage and Influence in the National Health Policy Domain. American Journal of Sociology, $99(6), 1455-1491$.

Godenhjelm S, Lundin RA and Sjöblom S (2015) Projectification in the Public Sector - The Case of the European Union. International Journal of Managing Projects in Business, 8(2).

Grabher G (2004) Learning in projects, remembering in networks? Communality, Sociality, and connectivity in project ecologies.pdf. European Urban and Regional Studies, 11(2), 103-123.

Granovetter M (1985) Economic action and social structure problems of embeddedness.pdf. The American Journal of Sociology, 91(3), 481-510.

Gulati R (1995) Does familiarity breed trust? The implications of repeated ties for contractual choice in alliances. Academy of Management Journal, 38(1), 85112.

Hartley J (2005) Innovation in governance and public services: Past and present. Public money and management, (January), 27-35.

Jordana J, Mota F and Noferini a. (2012) The role of social capital within policy networks: evidence from EU cohesion policy in Spain. International Review of Administrative Sciences, 78(4), 642-664.

Kauffeld-Monz M and Fritsch M (2013) Who Are the Knowledge Brokers in Regional Systems of Innovation? A Multi-Actor Network Analysis. Regional Studies, 47(5), 669-685.

Kim SE and Chang GW (2009) An empirical analysis of innovativeness in government: findings and implications. International Review of Administrative Sciences, 75(2), 293-310.

Klijn E-H (2008) Governance and Governance Networks in Europe. Public Management Review, 10(4), 505-525.

Koschatzky K, Kulicke M and Zenker A (2001) Innovation networks: Concepts and challenges in the European perspective. Heidelberg: Physica-Verlag.

International Review of

Administrative Sciences

$0(0) 1-21$

! The Author(s) 2016

Reprints and permissions:

sagepub.co.uk/journalsPermissions.nav

DOI: $10.1177 / 0020852315620291$ 
Loorbach D (2010) Transition Management for Sustainable Development: A Prescriptive, Complexity-Based Governance Framework. Governance, 23(1), 161-183.

Lundin RA and Söderholm A (1995) A Theory of the temporary organization.pdf. Scandinavian Journal of Management, 11, 437-455.

McCann P and Ortega-Argiles R (2013) Modern regional innovation policy. Cambridge Journal of Regions, Economy and Society, 6(2), 187-216.

Michels A. (2011) Innovations in democratic governance: how does citizen participation contribute to a better democracy? International Review of Administrative Sciences, 77(2), 275-293.

Ministry of Labor and the Economy (2014) EURA 2007 database. Ministry of Labor and the Economy.

Moore M and Hartley J (2008) Innovations in governance. Public Management Review, 10(1), 3-20.

Nan L (2001) Social Capital: A Theory of Social Structure and Action. Cambridge: Cambridge University Press.

Nonaka I and Takeuchi H (1995) The knowledge-creating company: How Japanese companies create the dynamics of innovation. New York: Oxford University Press.

OECD and Eurostat (2005) Oslo Manual. GUIDELINES FOR COLLECTING AND INTERPRETING INNOVATION DATA.

Project management Institute (2004) A Guide to the Project Management Body of Knowledge. 3rd ed. Pennylvania: Project Management Intitute Inc.

Provan KG and Kenis P (2007) Modes of Network Governance: Structure, Management, and Effectiveness. Journal of Public Administration Research and Theory, 18(2), 229-252. 
Provan KG, Fish a. and Sydow J (2007) Interorganizational Networks at the Network Level: A Review of the Empirical Literature on Whole Networks. Journal of Management, 33(3), 479-516.

Pryke S (2006) Projects as networks of relationships. In: Pryke S and Smyth H (eds), The Management of Complex Projects a relationship approach, Oxford: Blackwell Publishing Ltd, pp. 213-235.

Rowley J, Baregheh A and Sambrook S (2011) Towards an innovation-type mapping tool. Management Decision, 49(1), 73-86.

Schreier M (2014) Qualitative Content Analysis. In: Flick U (ed.), The SAGE Handbook of Qualitative Data Analysis, London: SAGE Publications Ltd., pp. 170-184.

Scott J (2007) Social Network Analysis a handbook. 2nd ed. London: SAGE Publications Ltd.

Skilton P and Dooley K (2010) The Effects of Repeat Collaboration on Creative Abrasion. The Academy of Management Review, 35(1), 118-134.

Sørensen E and Torfing J (2011) Enhancing Collaborative Innovation in the Public Sector. Administration \& Society, 43(8), 842-868.

Sørensen E and Torfing J (2012) Introduction Collaborative Innovation in the Public Sector. The Innovation Journal: The Public Sector Innovation Journal, 17(1), 1-14.

Suomen rakennerahastostrategia (2007) Suomen rakennerahastostrategia 20072013. [Finnish Structural Fund Strategy].

Torfing J, Peters GB, Pierre J, et al. (2012) Interactive Governance. Advancing the Paradigm. Oxford: Oxford University Press.

Uzzi B (1997) Social structure and competition in interfirm networks: The paradox of embeddedness. Administrative science quarterly, 42(1), 35-67.

Wirick DW (2009) Public-Sector Project Management. Meeting the Challenges and Achieving Results. Hoboken: John Wiley \& Sons, Inc.

International Review of

Administrative Sciences

$0(0) 1-21$

! The Author(s) 2016

Reprints and permissions:

sagepub.co.uk/journalsPermissions.nav

DOI: $10.1177 / 0020852315620291$ 
Sebastian Godenhjelm is a University instructor at the Swedish School of Social Science, and a Ph.D. student at the Department of Political and Economic Studies at the University of Helsinki in Finland. He is finishing his doctoral dissertation on project organizations and governance, processes, actors, and participatory procedures. He has previously conducted research for the Finnish Academy project on the Democratic impact of temporary governance instruments in regional development, and has conducted several evaluations for the Department of Justice, the Ministry of Labor and the Economy, the Ministry of Forestry and Agriculture as well as the think tank MAGMA. He is currently a board member of the Nordic Political Science Association (NoPSA), and the secretary of the Nordic Administrative Alliance's Finnish division (NAF).

Jan-Erik Johanson is a Professor of Public administration at the management school, University of Tampere, Finland. Currently, he is a head of a research project studying innovation capture and diffusion in public health services funded by the Finnish Funding Agency for Innovation TEKES. During the academic year 20052006 he acted as the Research Director at the Department of Political Science. Johanson was a Visiting Research Fellow at the Department of Government, Brunel University, and University of West London 1996-1997. His recent published work in English has appeared in Public Administration, International Review of Public Administration and Public Organization Review, among others. 
Figure 1. Summary of the results of the logistic regression analysis predicting innovation

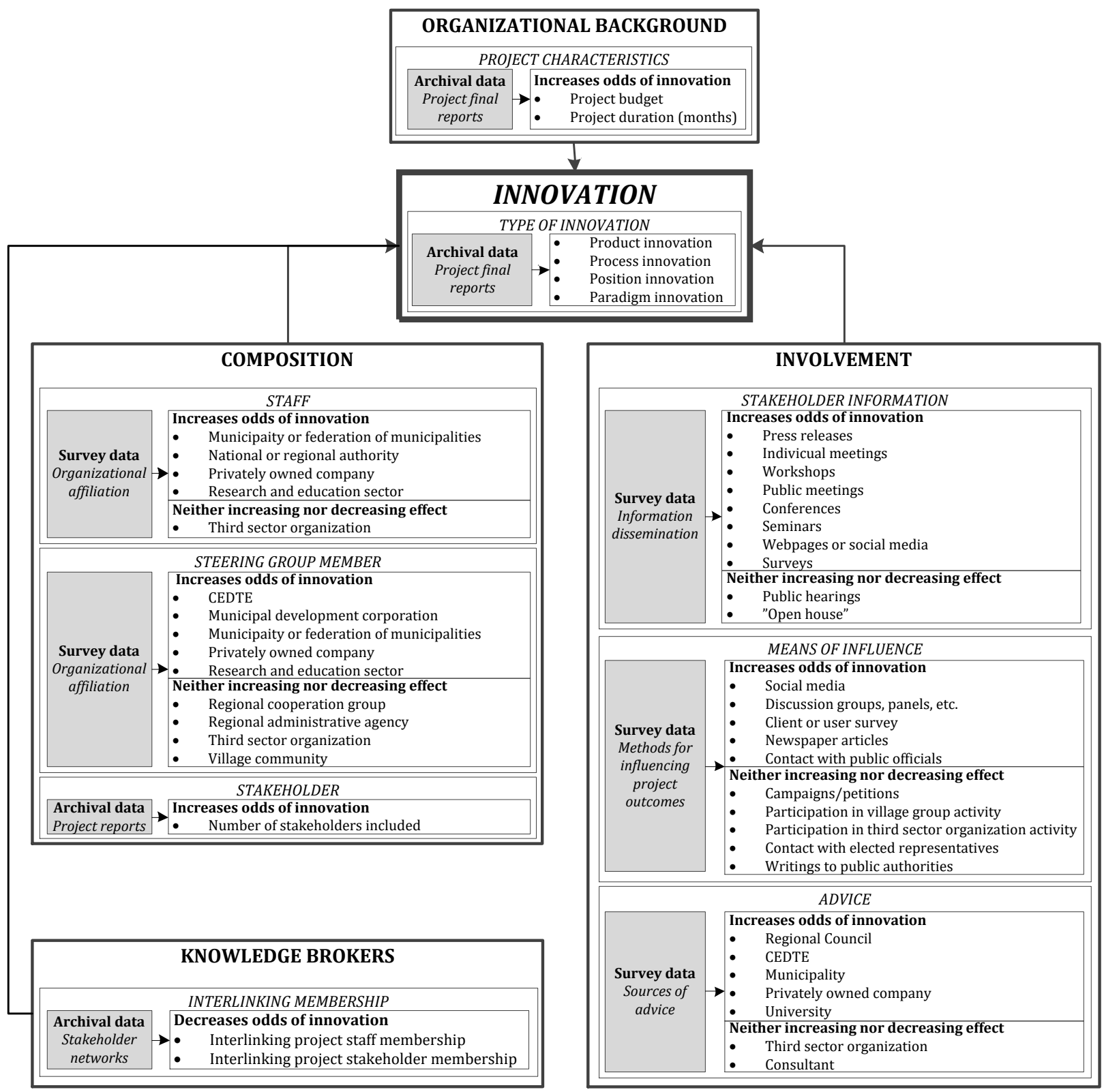

International Review of

Administrative Sciences

$0(0) 1-21$

! The Author(s) 2016

Reprints and permissions:

sagepub.co.uk/journalsPermissions.nav

DOI: $10.1177 / 0020852315620291$ 
Figure 2. Project external stakeholder involvement ( $N=275)$

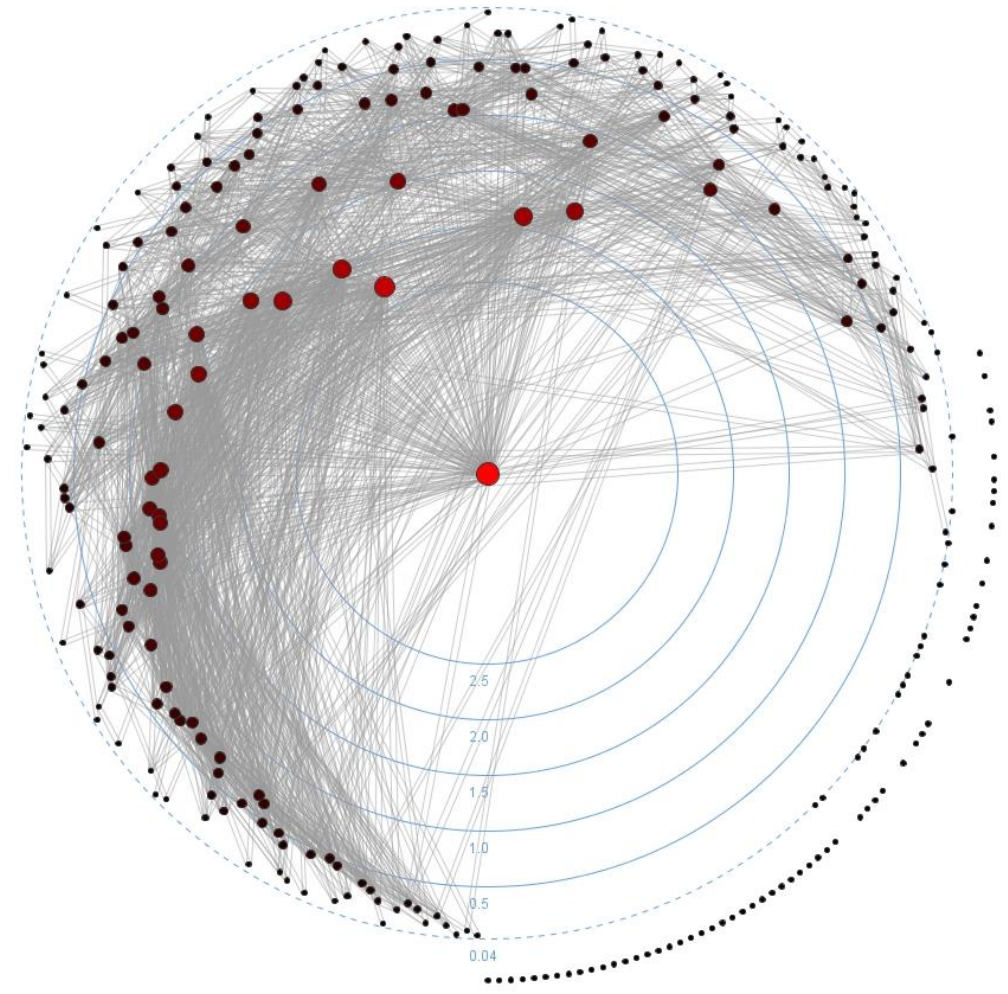

International Review of Administrative Sciences 0 (0) 1-21

! The Author(s) 2016

Reprints and permissions:

sagepub.co.uk/journalsPermissions.nav

DOI: 10.1177/0020852315620291 
Appendix 1. Summary of the results of the regression analysis

\begin{tabular}{|c|c|c|c|c|}
\hline & $\mathbf{B}$ & $\operatorname{Exp}(B)$ & $S E$ & Sig. \\
\hline \multicolumn{5}{|l|}{ ORGANIZATIONAL BACKGROUND } \\
\hline \multicolumn{5}{|l|}{ Project characteristics } \\
\hline Project budget (log) & .053 & 1.054 & .011 & $.000^{* *}$ \\
\hline Project duration (months) & .024 & 1.025 & .005 & $.000^{* *}$ \\
\hline \multicolumn{5}{|l|}{ COMPOSITION } \\
\hline \multicolumn{5}{|l|}{ Staff } \\
\hline Staff from municipality or federation of municipalities & .860 & 2.364 & .360 & $.017^{*}$ \\
\hline Staff from national or regional authority & 1.299 & 3.667 & .651 & $.046^{*}$ \\
\hline Staff from privately owned companies & .869 & 2.385 & .330 & $.009^{* *}$ \\
\hline Staff from research and education sector & .904 & 2.471 & .287 & $.002^{* *}$ \\
\hline Staff from third sector organization & .693 & 2.000 & .500 & .166 \\
\hline Number of stakeholders included (log) & .233 & 1.263 & .068 & $.001^{* *}$ \\
\hline \multicolumn{5}{|l|}{ Steering group member } \\
\hline Member from CEDTE & .799 & 2.222 & .401 & $.047^{*}$ \\
\hline Member from municipal development corporation & .718 & 2.050 & .273 & $.008^{* *}$ \\
\hline Member from municipality or federation of municipalities & .827 & 2.286 & .262 & $.002^{* *}$ \\
\hline Member from privately owned company & .717 & 2.048 & .266 & $.007^{* *}$ \\
\hline Member from research and education sector & .629 & 1.875 & .253 & $.013^{*}$ \\
\hline Member from regional cooperation group & .981 & 2.667 & .677 & .147 \\
\hline Member from regional administrative agency & 1.792 & 6.000 & 1.080 & .097 \\
\hline Member from third sector organization & .000 & 1.000 & .365 & 1.000 \\
\hline Member from village community & $1.099^{-}$ & .333 & 1.155 & .341 \\
\hline \multicolumn{5}{|l|}{ KNOWLEDGE BROKERS } \\
\hline Interlinking project staff member & $-1,73$ & .177 & .195 & $.000^{* *}$ \\
\hline Interlinking project stakeholder member & $-2,04$ & .130 & .213 & $.000^{* *}$ \\
\hline \multicolumn{5}{|l|}{ INVOLVEMENT } \\
\hline \multicolumn{5}{|l|}{ Stakeholder information } \\
\hline Stakeholder information by press releases & .731 & 2.077 & .239 & $.002^{* *}$ \\
\hline Stakeholder information by individual meetings & .658 & 1.931 & .229 & $.004^{* *}$ \\
\hline Stakeholder information by workshops & .629 & 1.875 & .253 & $.013^{*}$ \\
\hline Stakeholder information by public meetings & .891 & 2.437 & .297 & $.003^{* *}$ \\
\hline Stakeholder information by conferences & .857 & 2.357 & .319 & $.007^{* *}$ \\
\hline Stakeholder information by seminars & .732 & 2.080 & .243 & $.003^{* *}$ \\
\hline Stakeholder information by webpage or social media & .841 & 2.318 & .255 & $.001^{* *}$ \\
\hline Stakeholder information by surveys & .944 & 2.571 & .315 & $.003^{* *}$ \\
\hline Stakeholder information by public hearings & .336 & 1.400 & .586 & .566 \\
\hline Stakeholder information by "open house" & .619 & 1.857 & .331 & .062 \\
\hline
\end{tabular}

International Review of Administrative Sciences 0(0) 1-21

! The Author(s) 2016

Reprints and permissions:

sagepub.co.uk/journalsPermissions.nav

DOI: 10.1177/0020852315620291 


\section{Means of influence}

Social media

$\begin{array}{llll}1.281 & 3.600 & .506 & .011^{*}\end{array}$

Discussion groups, panels, etc.

$\begin{array}{llll}.770 & 2.160 & .242 & .001^{* *}\end{array}$

Client or user surveys

$\begin{array}{llll}1.128 & 3.091 & .347 & .001^{* *}\end{array}$

Newspaper articles

$\begin{array}{llll}.629 & 1.875 & .253 \quad .013^{*}\end{array}$

Contact with public officials

$\begin{array}{llll}.693 & 2.000 & .255 & .007^{* *}\end{array}$

Campaigns, petitions, etc.

Participation in village community activity

$\begin{array}{llll}.693 & 2.000 & .866 & .423\end{array}$

Participation in third sector organization activity

$\begin{array}{llll}.000 & 1.000 & .707 & 1.000\end{array}$

Contact with elected representatives

$\begin{array}{llll}.539 & 1.714 & .476 & .257\end{array}$

Writings to public authorities

$\begin{array}{lll}.624 & 1.867 & .320\end{array}$

.051

Source of advice

Advice from regional council

$\begin{array}{lll}.511 & 1.667 \quad .516\end{array}$

.323

Advice from CEDTE

Advice from municipality

$\begin{array}{llll}.847 & 2.333 & .261 & .001^{* *}\end{array}$

Advice from privately owned company

$\begin{array}{lll}1.322 & 3.750 & .563\end{array}$

$.019^{*}$

Advice from University

$\begin{array}{lll}.981 & 2.667 & .391\end{array}$

$.012^{*}$

$\begin{array}{llll}.728 & 2.071 & .325 & .025^{*}\end{array}$

Advice from third sector organization

$\begin{array}{lll}.659 & 1.933 \quad .318\end{array}$

$.038^{*}$

Advice from consultant

$\begin{array}{lll}.560 & 1.750 & .627\end{array}$

.372

Note: ${ }^{*} \mathrm{p}<.05 ;{ }^{* *} \mathrm{p}<.01$

\section{Notes}

1 The survey questions can be obtained from the corresponding author

2 Research assistants were responsible for the coding which showed coding consistency and intercoder reliability.

${ }^{3} 11$ of the 37 projects produced hybrid innovation types.

${ }^{4}$ All results of the logistic regression analysis summarized in appendix 1.

International Review of Administrative Sciences $0(0) 1-21$

! The Author(s) 2016

Reprints and permissions:

sagepub.co.uk/journalsPermissions.nav

DOI: 10.1177/0020852315620291 
5 The 275 nodes represent projects and the 7,422 edges links between projects established by stakeholders categorized as privately owned companies. The node's centrality is the number of links incident upon the node, and is illustrated by size and placement.

${ }^{6} \mathrm{~N}=114$

${ }^{7} \mathrm{~N}=113$

${ }^{8} \mathrm{~N}=111$

International Review of Administrative Sciences $0(0)$ 1-21

! The Author(s) 2016

Reprints and permissions:

sagepub.co.uk/journalsPermissions.nav

DOI: 10.1177/0020852315620291 